\title{
CHANGES IN THE ORGANIC PROCESSING IN POLAND IN THE YEARS 2004-2017
}

\author{
Elżbieta Brągiel, MSc Eng ${ }^{1 *}$; Teresa Miś, $\mathrm{PhD}^{2^{* *}}$ \\ ${ }^{1}$ Institute of Health and Economy, Stanisław Pigoń State Higher Vocational School in Krosno \\ 2 Faculty of Economics, University of Rzeszów \\ ${ }^{*}$ https://orcid.org/0000-0001-7393-1381 \\ ${ }^{* *}$ https://orcid.org/0000-0002-5164-0804
}

\begin{abstract}
The processing of organic products in Poland develops, the number of organic entities increases and there are changes in the structure in individual industries. The aim of this article was to evaluate the trends and the degree of changes that have occurred in the number of processing plants and the structure of organic processing industries in Poland in the years 2004-2017. The analysis covered eight industries of processing organic products. Over thirteen years, there has been a steady increase in the number of organic processing plants, despite the low amount of organic production and the lack of developed and sustainable forms of cooperation at various levels - from the producer to the consumer. The low consumption of organic products (compared to European countries) also shows down and shapes changes that occur in the structure in particular processing sectors.
\end{abstract}

Key words: organic processing, organic farming, processing industries JEL codes: Q, O

\section{INTRODUCTION}

The organic processing is a key segment of the food system and it is directly connected with the development of the organic farming sector. Concentration of organic production and processing is needed (Gołębiewski, 2019). Organic processing in its production mainly uses raw materials from organic farming. Other authors emphasize the great importance of ecological production and quality of the natural environment in the implementation of sustainable rural development at regional and local level. The condition for implementing individual components of the sustainable development paradigm is the active participation of rural resi- dents and other people (Diez, Izquierdo and Malagon, 2016; Rotaru et al., 2017). It is subject to strict regulations on the basis of Community and national acts that are related to the organic farming and processing.

Pursuant to the applicable regulations, a processed product may be labeled as organic if it includes at least $95 \%$ of ingredients of agricultural origin and if it is produced from products obtained with the use of ecological methods. The other ingredients that may be used are listed in Annex IX of the EU Commission Regulation 889/2008 or permitted on the basis of a temporary permit issued by a Member State.

The market of organic products in Poland is still shaping. There are dynamic changes in this market.

${ }^{1}$ Corresponding author: Rynek 1, 38-400 Krosno, Poland, elabragiel@interia.pl, +4813 4375580

${ }^{2}$ Corresponding author: Ćwiklińskiej 2, 35-601 Rzeszów, Poland, tmis@ur.edu.pl, +4817 8721639 
Not only the quality of products, but also the degree of their processing and availability has become important (Nowogródzka, 2012). The specific determinants of the market for organic products also include the level of economic development, specific behavior and ecological awareness of consumers, wealth of society and agricultural policy (Domagalska and Buczkowska, 2015). According to the report of the International Federation of Organic Agriculture Movements (IFOAM), the EU and the Institute for Organic Agriculture Research FiBL, in 2017, retail sales in Europe amounted to 37 billion EUR (34.3 billion EUR in the European Union). In particular countries, the sales amounted to 10 billion EUR (Germany), 7.9 billion EUR (France) and 3.1 billion EUR (Italy). In Poland, the value of retail sales amounted to 235 million EUR (Willer and Lernoud, 2019). Demand for organic products is growing dynamically, both in the EU and in our country. Unfortunately, in Poland it is not fully satisfied with domestic production - both in terms of quantity and variety of assortment.

The development of organic processing is one of the most important factors determining the improvement of the supply side of the organic food market (Śliwowska, 2012). The development of organic food processing has also been noticed in the Framework Action Plan for Food and Organic Farming in Poland for the years 2014-2020, which is additionally included as one of the strategic projects in the Strategy for Responsible Development.

The aim of the article was to present a view about the processes that took place in the number and structure of organic processing in Poland in particular industries in the years 2004-2017.

\section{MATERIAL AND METHODOLOGY OF RESEARCHES}

The source material included data from the Agricultural and Food Quality Inspection (Polish acronym IJHARS) contained in the reports and information on the state of organic farming in Poland in the years 2004-2017 and data from the International Federation of Organic Agriculture Movements (IFOAM) and the Institute for Organic Agriculture Research (FiBL). Scientific studies were used in the discussion.
The researches were carried out in processing enterprises referred to as preparation entities. According to the definition indicated in Art. 2 letter $i$ of the Council Regulation (EC) 834/2007, "preparation" means preservation or processing operations for organic farming products, including slaughter and cutting of products of animal origin, as well as packaging, marking or making changes in the labelling relating to the organic production method. The collected data were grouped and indicators of the dynamics of the structure for organic processing in Poland were calculated - broken down by industry. Moreover, statistical data was analysed. The results are presented in a descriptive form, tables and figures.

\section{RESULTS AND DISCUSSION}

Changes in the number of organic processing plants in Poland in the years 2004-2017 have an increasing tendency (Fig. 1). In the analysed period, the number of processing plants increased - from 55 in 2004 to 795 in 2017 , i.e. by $1,345.45 \%$, and the dynamics of changes was varied in individual years. Despite the thirteen-fold increase in the number of organic processing plants, Michalik (2016) thinks that some of these plants do not start processing due to limited access to raw materials. As it is pointed out by Luczka (2016) in her researches, the majority of entities ( $80 \%$ ) simultaneously carry out processing of conventional and organic raw materials, and their share in particular processing plants is diversified.

Since Poland's accession to the European Union, the number of certified organic farms has increased several times. In 2004, there were 3,705 organic farms, and in $2017-20,257$ organic farms - despite the decrease in their number from 2014 (the Agricultural and Food Quality Inspection webpage https:// ijhars.gov.pl/raporty-i-analizy.html). Unfortunately, the dynamic growth in the number of farms does not translate into the same degree of growth in commodity production. The decrease in the number of organic farms since 2014 by 4,572 farms and their area by 162,923 ha has not translated into a reduction in the number of organic processing plants and there is still a rising trend of these plants. As noted by Kułyk and Michałowska (2016), until 2013, a significant part of 


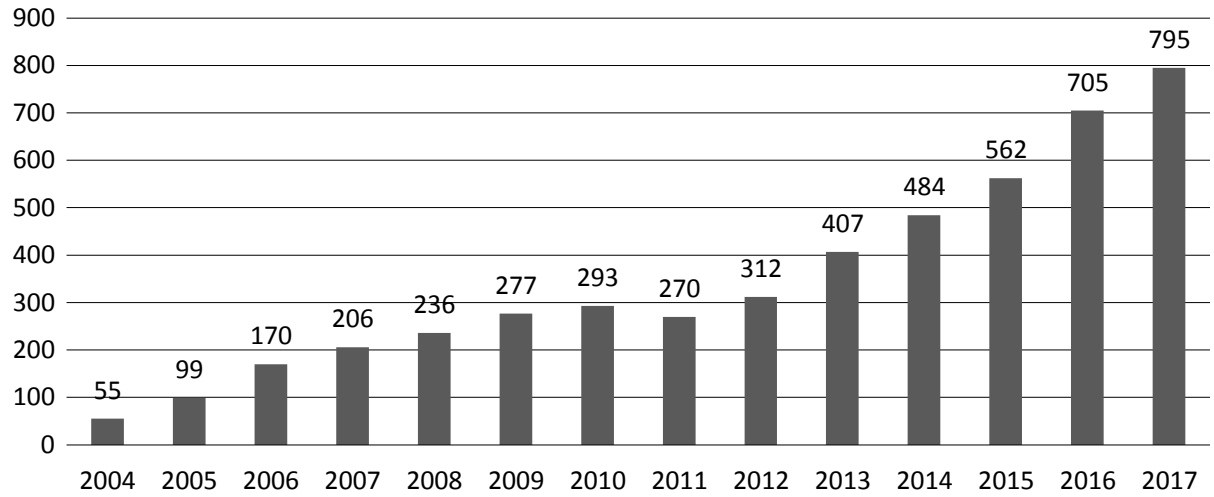

Figure 1. The number of organic processing plants in Poland

Source: own study based on reports on the state of organic farming in Poland available at the Agricultural and Food Quality Inspection webpage https://ijhars.gov.pl/raporty-i-analizy.html

the certified organic area included permanent pasture. In the structure of crops with plants for feed, permanent pasture constituted 66\% (Agricultural and Food Quality Inspection, 2013-2014, 2015), with a small share of farms with animal breeding (Brodzińska, 2014). In the following years, this trend did not change significantly, and in 2016 - both of these groups accounted for $58 \%$, and farms conducting (simultaneously) plant and animal production had only $16.8 \%$ of share, with $83.2 \%$ of farms carrying out only plant production (Agricultural and Food Quality Inspection, 2015-2016, 2017). Researches of Jasiński, Michalska and Śpiewak (2014) additionally indicate that the adopted support system does not encourage the development of production that would be directed to the market. This translates into a high index of organic farms in Poland per one processing plant with (at the same time) low market value. In 2017 , on average, there were 25 agriculture producers and 482 ha of organic arable lands per one processing plant after the conversion period (the Agricultural and Food Quality Inspection webpage https://ijhars. gov.pl/raporty-i-analizy.html).

The currently available data shows that the largest share in the processing of organic products in the years 2010-2016 had fruit and vegetable processing industry (Table 1). The share of this industry fluctuated during the analysed period - on average, it was at

Table 1. Share of industries in the processing of organic products in Poland in the years 2010-2016 (\%)

\begin{tabular}{|l|c|c|c|c|c|c|c|}
\hline Specification & 2010 & 2011 & 2012 & 2013 & 2014 & 2015 & 2016 \\
\hline Processing of fruits and vegetables & 32.4 & 32.0 & 31.6 & 29.2 & 34.1 & 32.1 & 31.1 \\
\hline Processing of grain mill products & 20.1 & 23.5 & 24.2 & 23.8 & 19.8 & 20.3 & 17.2 \\
\hline Processing of coffee and tea & 6.0 & 6.0 & 5.0 & 6.3 & 4.8 & 5.0 & 4.9 \\
\hline Processing of meat and fish & 5.1 & 6.5 & 7.0 & 4.9 & 7.0 & 7.7 & 6.1 \\
\hline Processing of milk and cheese production & 2.7 & 3.0 & 4.7 & 3.6 & 3.1 & 3.1 & 4.9 \\
\hline Processing of vegetable and animal fats & 1.3 & 1.8 & 2.4 & 2.7 & 2.4 & 2.4 & 3.5 \\
\hline Processing of sugar & 0.3 & 1.0 & 0.3 & 1.6 & 1.5 & 1.2 & 1.5 \\
\hline Processing of other agri-food products & 32.1 & 25.8 & 24.8 & 27.9 & 27.3 & 28.2 & 30.8 \\
\hline
\end{tabular}

Source: own study based on data from the reports about the state of organic farming in Poland in the years 2011-2012, 2013-2014, 2015-2016. 
the level of $31.8 \%$. The highest share was recorded in 2014 , at the level of $34.1 \%$, and the lowest one - a one year earlier (4.9\% less). When analysing the dynamics of changes, the highest and the only increase in dynamics occurred in 2014 - by $16.8 \%$ in relation to 2013 and by $5.2 \%$ in relation to 2010 (Table 2). On the other hand, the largest decrease in share (by 7.6\%) occurred in 2013, and in 2015 (by 5.9\% compared to the previous year). Nowak and Szewczyk (2015) indicate that the majority of companies are engaged in the processing of fruits and vegetables, because they are relatively the most easily available. In Poland, there are relatively many organic farms that deal with cultivation on a large area, and the share of this production group in Europe is significant (Komorowska, 2014).

The second place in the processing industry, according to the industries, is occupied by the processing of grain milling (Table 1). Until 2012, the trend was growing, and then (from 2014) there was a downward trend. The average share of this industry in the analysed period was $21.3 \%$. The highest one was in the years 2011-2013, over $23.5 \%$. The lowest share occurred in 2016 , only $17.2 \%$, i.e. $7 \%$ less than in 2012 (with the highest share). The highest increase in the share of cereal milling processing was in 2011, by $16.9 \%$ in relation to the previous year and in the years 2011-2013 in relation to 2010 (Table 2). On the other hand, the highest reduction in share was recorded in 2014 , by $16.8 \%$ and in 2016 - by $15.3 \%$ in relation to the previous year.

The share of the tea and coffee processing was characterized by a variable trend, ranging from $4.8 \%$ (in 2014) to $6.3 \%$ (in 2013) (Table 1). The last three years presented a stabilized level, but with the lowest share. The largest increase in the share in the processing of coffee and tea was noted in 2013 (by $26 \%$ ) compared to the previous year, while the larg-

Table 2. Dynamics of changes in the share of processing of organic products broken down by industries (\%)

\begin{tabular}{|l|c|c|c|c|c|c|c|}
\hline \multicolumn{2}{|l|}{ Specification } & 2011 & 2012 & 2013 & 2014 & 2015 & 2016 \\
\hline \multirow{2}{*}{ Processing of fruits and vegetables } & $* \mathrm{a}$ & -1.2 & -1.3 & -7.6 & 16.8 & -5.9 & -3.1 \\
\cline { 2 - 8 } & $* * \mathrm{~b}$ & -1.2 & -2.5 & -9.9 & 5.2 & -0.9 & -4.0 \\
\hline \multirow{2}{*}{ Processing of grain mill products } & $\mathrm{a}$ & 16.9 & 3.0 & -1.7 & -16.8 & 2.5 & -15.3 \\
\cline { 2 - 8 } & $\mathrm{b}$ & 16.9 & 20.4 & 18.4 & -1.5 & 1.0 & -14.4 \\
\hline \multirow{2}{*}{ Processing of coffee and tea } & $\mathrm{a}$ & 0.0 & -16.7 & 26.0 & -23.8 & 4.2 & -2.0 \\
\hline & $\mathrm{b}$ & 0.0 & -16.7 & 5.0 & -20.0 & -16.7 & -18.3 \\
\hline \multirow{2}{*}{ Processing of meat and fish } & $\mathrm{a}$ & 27.5 & 7.7 & -30.0 & 42.9 & 10.0 & -20.8 \\
\hline \multirow{2}{*}{ Processing of milk and cheese production } & $\mathrm{b}$ & 27.5 & 37.3 & -3.9 & 37.3 & 51.0 & 19.6 \\
\hline \multirow{2}{*}{ Processing of vegetable and animal fats } & $\mathrm{a}$ & 11.1 & 56.7 & -23.4 & -13.9 & 0.0 & 58.1 \\
\hline & $\mathrm{b}$ & 11.1 & 74.1 & 33.3 & 14.8 & 14.8 & 81.5 \\
\hline \multirow{2}{*}{ Processing of sugar } & $\mathrm{a}$ & 38.5 & 33.3 & 12.5 & -11.1 & 0.0 & 45.8 \\
\hline & $\mathrm{b}$ & 38.5 & 84.6 & 107.7 & 84.6 & 84.6 & 169.2 \\
\hline \multirow{2}{*}{ Processing of other agri-food products } & $\mathrm{a}$ & 233.3 & -70.0 & 433.3 & -6.3 & -20.0 & 25.0 \\
\hline & $\mathrm{b}$ & 233.3 & 0.0 & 433.3 & 400.0 & 300.0 & 400.0 \\
\hline & $\mathrm{a}$ & -19.6 & -3.9 & 12.5 & -2.2 & 3.3 & 9.2 \\
\hline
\end{tabular}

${ }^{*} \mathrm{a}-$ dynamics previous year $=100 ;{ }^{* *} \mathrm{~b}-$ dynamics year $2010=100$.

Source: own study based on data from the reports about the state of organic farming in Poland in the years 2011-2012, 2013-2014, 2015-2016. 
est decrease a year later - by $23.8 \%$ (Table 2). The largest decrease in the share in relations to the base year (2010) was recorded in 2012 and in the years 2014-2016.

The processing of meat and fish is characterized by a trend of cyclical fluctuations (Table 1). In 2010, the share decreased from $6.6 \%$ to $5.1 \%$ (Agricultural and Food Quality Inspection, 2009-2010, 2011). From 2011-2012, the share of meat and fish processing increased from $5.1 \%$ to $7 \%$, and in 2013 in decreased to $4.9 \%$. Next to, it increased to $7 \%$ and $7.7 \%$ (respectively) in the next years 2014-2015. In 2016 , the share decreased again to the level of $6.1 \%$. The largest increase in the share of meat and fish processing was recorded in 2014 as compared to the previous year, by $43 \%$, and the largest decrease was observed a year earlier, by $30 \%$ (Table 2). An increase by $51 \%$ in the share of processing occurred in 2015 compared to 2010 .

Luczka (2016) indicates a small number of meat processing plants and slaughterhouses, because animal production in many farms is small or mainly concentrated in Podlaskie and Małopolskie Voivodeships.

Milk processing and cheese production had the highest share in the processing of organic products in the years 2012 (4.7\%) and 2016 (4.9\%) (Table 1). The share in the examined period fluctuated between $2.7 \%$ and $4.9 \%$. It is difficult to indicate the trend. The highest increases in the share of milk and cheese processing occurred in 2012 and 2016 - respectively by $56.7 \%$ and $58.1 \%$ compared to the previous year and by $74.1 \%$ and $81.5 \%$ in relation to 2010 (Table 2). Milk processing and cheese production are not sufficiently developed. The situation of milk processing is better. There is shortage of highly processed milk products such as yogurt, kefir and homogenized cream cheese on the market (Łuczka, 2016).

The processing of vegetable and animal fats was characterized by an upward trend (Table 1). Starting from the share at the level of $1.3 \%$ in 2010 , the share grew to $2.7 \%$ in 2013 , and then it slightly decreased by $0.3 \%$ in the next two years. In 2016, it reached the level of $3.5 \%$. By analogy, the only decrease in the share in relation to the previous year was recorded in 2014 , by $11.1 \%$ (Table 2 ). High increases in com- parison to the base year occurred in 2016 (169\%), $2013(107.7 \%)$ and in years 2012, 2014 and 2015 (84.6\%).

The share of organic processing of sugar is at a very low level - it did not exceed $1.6 \%$ in the analyzed period (Table 1). The lowest share was recorded in the years 2010 and 2012 - at the level of $0.3 \%$. Since 2013 , the share of sugar processing has stabilized and it is on average at $1.45 \%$. The dynamics in sugar processing was very variable (Table 2). In 2011 and 2013, the share increased by $233 \%$ and $433 \%$ (respectively) compared to the previous year, and in 2012 - it decreased by $70 \%$. In all years, a high increase in the share of sugar processing occurred also in relation to 2010, expect for 2012, when the share of processing was the same as in the base year.

A large share presents the group of processing of other agri-food products, which includes spices, beverages, cocoa, chocolate, confectionary, ready meals and other processed products. The highest share of this group in the processing of organic products was observed in $2010-32.1 \%$. In 2011 and 2012, the share was reduced to $6.3 \%$ and $7.3 \%$ (respectively) as compared to 2010 (Table 1). Since 2013, there is an upward trend. In 2016, the share was higher by $6 \%$ and amounted to $30.8 \%$ compared to the lowest one, which occurred in 2012. The dynamics index was negative in each subsequent year compared to the base year, i.e. 2010 - the highest decrease occurred in 2010 - by $22.7 \%$ and in 2011 - by $19.6 \%$ (Table 2 ). On the other hand, the highest increase in the share of this industry was noted in 2013 , by $12.5 \%$, but in relation to the previous year.

American researches show that organic production gives the opportunity to obtain high-quality, natural and safe products. Therefore, despite its niche range, it is growing dynamically all over the world. The support received by organic production is differently assessed by organic producers. Processing and consumers play an important role in the development process of this production, because the demand for organic food is growing rapidly (Dimitri and Oberholtzer, 2005).

Production and processing in Poland, despite many favourable natural, economic or social condi- 
tions, is not at an optimally high level, especially in comparison to Europe. The development of processing is heavily dependent on consumer consumption. In the European Union, in 2017, an average resident spent 67 EUR on organic products. In Europe, it was 47 EUR (Willer and Lernoud, 2019). In 2017, the highest amount on organic products per one resident was spent in Switzerland - 288 EUR, Denmark - 278 EUR and Sweden - 237 EUR (Fig. 2). In Poland, about 6 EUR per person is spent on organic products, i.e. approx. 11 times less than the average resident of the European Union and 48 times less than a resident of Switzerland.

The most commonly purchased organic products include: fruits, vegetables, dairy products, cereal and soy products. Consumers point to the lack of meat and its products, as well as dairy products (Komorowska, 2009). Customers on the organic food market expect greater diversity of assortment, in particular they are looking for dairy, meat and confectionery products (Śliwowska, 2012; Łuczka, 2016).

Food processing, especially organic processing, depends to a large extent on the raw material base and sales market (Śliwowska, 2012), which (in turn) translates into changes in the share in the structure of each industry. According to Kociszewki (2014), production and processing are a weak link in the organic food economy characterized by poor coherence of its components. In researches of Łuczka (2016) and Śliwowska (2012), agricultural producers usually indicated the lack of sufficient number of processing plants as one of the reasons for difficulties in selling some products, such as milk and meat. In turn, processors think that the low level of production is caused by the lack of continuity of supply and dispersion of organic farms. According to Brodzińska (2010), agri-food processing requires spatial concentration. The results of Kociszewski's studies (2014) indicate that organic farmers are weakly connected with formalized distribution channels. Śliwowska (2012) indicates inadequacy of supply to the demand's place of occurrence. A very good example for the realization of the concept of sustainable development and reconciliation of the production, processing and sale of organic products is Bavaria, where many organizations help in maintaining the highest quality of production. Such an example in Bioland (study trip to Bavaria in June 2018 within the framework of the RDP 2014-2020 technical assistance program).

\section{SUMMARY}

The analysis shows that the number of organic processing plants is systematically growing in Poland, which should be evaluated as a very positive phenomenon. The largest share in the processing of organic products was demonstrated by the processing of fruits and vegetables and the processing of grain mill products. The share of these industries remained in the analyzed years at a relatively equal level with a slight downward trend. Based on the literature, it has

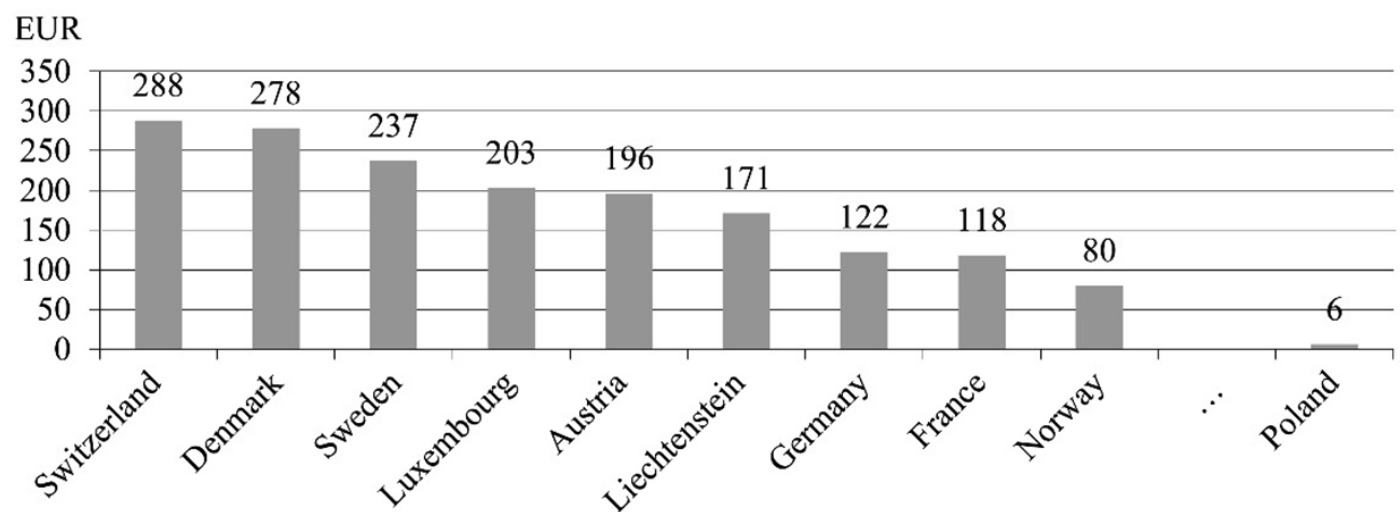

Figure 2. Countries in Europe with the highest consumption of organic products per one person in 2017 Source: own study based on Willer and Lernoud (2019). 
been found that there are barriers in the development of processing, e.g. lack of developed and permanent forms of cooperation at various levels (from the producer to the consumer). Low consumption of organic products (compared to European countries) also slows down and shapes changes that take place in the structure in individual industries of processing. In order to improve the production capacity of organic processing plants, it seems necessary to change the financing of the organic production, as well as closer forms of cooperation between farmers and processors in order to meet the needs of the processing industry and the entire organic market.

\section{REFERENCES}

1. Brodzińska, K. (2010). Rozwój rolnictwa ekologicznego w Polsce na tle uwarunkowań przyrodniczych i systemu wsparcia finansowego [Organic Farming Development in Poland in Context of Environmental Conditions and Financial Support System]. Zeszyty Naukowe SGGW. Problemy Rolnictwa Światowego, 10 (25), pp. 12-21.

2. Brodzińska, K. (2014). Rolnictwo ekologiczne - tendencje i kierunki zmian [Organic farming - trends and directions of changes]. Zeszyty Naukowe SGGW. Problemy Rolnictwa Światowego, 14 (3), pp. 27-36.

3. Commission Regulation (EC) $889 / 2008$ of 5 September 2008 laying down detailed principles for the implementation of the Council Regulation (EC) No 834/2007 on organic production and labeling of organic products with regard to organic production, labeling and control.

4. Diez, M.A., Izquierdo, B., Malagon, E. (2016). Increasing the Use of Evaluation Through Participation: The experience of a rural sustainable development plan evaluation. Environmental Policy and Governance, 26, pp. 366-376.

5. Dimitri, C., Oberholtzer, L. (2005). Market-Led Versus Government-Facilitated Growth Development of the U.S. and EU Organic Agricultural Sectors. WRS-05-05 Economic Research Service/USDA.

6. Domagalska, J., Buczkowska, M. (2015). Rolnictwo ekologiczne - szanse i perspektywy rozwoju [Organic farming - opportunities and perspectives]. Problemy Higieniczno-Epidemiologiczne, 96 (2), pp. 370-376.

7. Gołębiewski, J. (2019). Systemy żywnościowe w warunkach gospodarki cyrkularnej. Studium porównawcze krajów Unii Europejskiej [Food systems in circular economy. Comparative study of European Union countries]. Wydawnictwo SGGW, Warszawa.
8. IJHARS [Agricultural and Food Quality Inspection] (2013). Raport o stanie rolnictwa ekologicznego w Polsce w latach 2011-2012 [Report on the state of organic farming in Poland in 2011-2012]. Warszawa.

9. IJHARS [Agricultural and Food Quality Inspection] (2015). Raport o stanie rolnictwa ekologicznego w Polsce w latach 2013-2014 [Report on the state of organic farming in Poland in 2012-2014]. Warszawa.

10. IJHARS [Agricultural and Food Quality Inspection] (2017). Raport o stanie rolnictwa ekologicznego w Polsce w latach 2015-2016 [Report on the state of organic farming in Poland in 2015-2016]. Warszawa.

11. IJHARS [Agricultural and Food Quality Inspection]. Raporty i analizy [Reoports and analyses]. Retrieved from: https://ijhars.gov.pl/raporty-i-analizy.html [Accessed 27.05.2019].

12. Jasiński, J., Michalska, S., Śpiewak, R. (2014). Rolnictwo ekologiczne jako czynnik rozwoju lokalnego [Organic farming as a factor of local growth]. Wieś i Rolnictwo, 4 (165), pp. 145-158.

13. Kociszewski, K. (2014). Bariery i czynniki sprzyjające funkcjonowaniu gospodarstw ekologicznych w świetle wyników ogólnopolskich badań ankietowych [Barriers and factors favourable for functioning of organic farms in the light of nationwide questionnaire survey]. Roczniki Naukowe SERiA, 16 (2), pp. 129-134.

14. Komorowska, D. (2009). Rozwój produkcji i rynku żywności ekologicznej [Development of organic production and market of organic food]. Roczniki Naukowe SERiA, 11 (3), pp. 183-187.

15. Komorowska, D. (2014). Rozwój produkcji ekologicznej i rynku żywności ekologicznej na świecie [Development of organic production and organic food market in the world]. Roczniki Naukowe SERiA, 16 (6), pp. 254-262.

16. Kułyk, P., Michałowska, M. (2016). Stan rozwoju rolnictwa ekologicznego w Polsce w latach 2004-2014 [The status of development of organic farming in Poland in the years 2004-2014]. Zeszyty Naukowe SGGW. Ekonomika i Organizacja Gospodarki Żywnościowej, 113, pp. 17-32.

17. Łuczka, W. (2016). Mocne i słabe strony przetwórstwa ekologicznego [Strengths and weaknesses of organic food processing]. Roczniki Naukowe SERiA, 18 (5), pp. 143-148.

18. Michalczyk, J. (2016). Rynek żywności ekologicznej w warunkach członkostwa Polski w Unii Europejskiej [The market of organic food under conditions of Poland's membership in the European Union]. Prace 
Proceedings of the 2019 International Scientific Conference 'Economic Sciences for Agribusiness and Rural Economy' No 3, Warsaw, 5-7 June 2019, pp. 52-59

Naukowe Uniwersytetu Ekonomicznego we Wrocławiu, 448, pp. 178-192.

19. Ministerstwo Rolnictwa i Rozwoju Wsi [The Ministry of Agriculture and Rural Development] (2018). Ramowy Plan Działań dla Żywności i Rolnictwa Ekologicznego w Polsce na lata 2014-2020 [Framework Action Plan for Food and Organic Farming in Poland for the years 2014-2020]. Warszawa.

20. Nowogródzka, T. (2012). Stan i perspektywy rozwoju rolnictwa ekologicznego w Polsce [Current status and prospects of organic farming in Poland]. Zeszyty Naukowe SGGW. Problemy Rolnictwa Światowego, 12 (27), 2, pp. 54-64.
21. Rotaru, A., Pop, J., Vatca, S., Bunea, A., Andronie, L., Vatsa, A. (2017). Research on the Degree of Rural Development Using Statistical Indicators. ProEnvironment, 10, p. 255-260.

22. Śliwowska, E.K. (2012). Zaplecze surowcowe a rozwój przetwórstwa ekologicznego we wschodniej Polsce [Raw material base and development organic processing in Eastern Poland]. Roczniki Naukowe SERiA, 14 (5), pp. 198-202.

23. Willer, H., Lernoud, J. (eds.). (2019). The World of organic agriculture. Statistics \& Emerging Trends 2019. FiBL \& IFOAM - organics international. 